\title{
Equine Chorionic Gonadotropin Treatment 11 Days After Artificial Insemination Reduces Pregnancy and Lambing Rates in Creole Ewes
}

\author{
Ulises S. Quispe-Gutiérrez ${ }^{1 *}$, Raymundo Rangel-Santos², Sergio A. Ayala-Mariano33, \\ JODI L. BERNDTSON ${ }^{4}$
}

\begin{abstract}
${ }^{1}$ Faculty of Veterinary Medicine and Zootechnics, Micaela Bastidas National University of Apurimac, Abancay, Apurimac, Peru; ${ }^{2}$ Chapingo Autonomous University, Department of Zootechnics, Postgraduate in Animal Production, State of Mexico, Mexico; ${ }^{3}$ Chapingo Autonomous University, Department of Zootechnics, State of Mexico, Mexico; ${ }^{4}$ University of Wisconsin, Madison, Department of Animal Sciences, WI, USA.
\end{abstract}

\begin{abstract}
This study evaluated the effects of equine chorionic gonadotropin (eCG), 11 days after artificial insemination (AI) on pregnancy and lambing rates in Creole ewes. After laparoscopic insemination, ewes were randomly assigned to either eCG (nulliparous, $\mathrm{n}=14$ and multiparous, $\mathrm{n}=16$ ) or no eCG (nulliparous, $\mathrm{n}=13$ and multiparous, $\mathrm{n}=15$ ) treatment. On day 11 (day zero=AI) $330 \mathrm{IU}$ of eCG was administered IM to eCG treatment ewes. Blood samples were taken on day 11 and 15 to determine the estradiol and progesterone concentrations. The presence or absence of large follicle and large corpus luteum were evaluated on day 15 , pregnancy on day 35 by ultrasound, then the lambing rate. In ewes, treatment with eCG increased the number of large follicles (eCG, 11/30 vs. No eCG, 4/28; $\mathrm{p}=0.041$ ), turgid uteruses (eCG, $13 / 30$ vs. No eCG, 1/28; $\mathrm{p}=0.005$ ) and large corpora lutea (eCG, 15/30 vs No eCG, 6/28; $\mathrm{p}=0.013$ ). There were higher concentrations of estradiol-17 $ß\left(10.43 \pm 0.42\right.$ vs. $\left.6.24 \pm 0.25 \mathrm{pg} \mathrm{mL} \mathrm{m}^{-1} ; \mathrm{p}=0.0001\right)$ and serum progesterone $\left(8.22 \pm 0.21\right.$ vs. $\left.5.28 \pm 0.19 \mathrm{ng} \mathrm{mL}^{-1} ; \mathrm{p}=0.0001\right)$ in $\mathrm{eCG}$ treated ewes. However, $\mathrm{eCG}$ reduced the pregnancy rate (eCG, $13 / 30$ vs. no eCG, 23/28; $p=0.003$ ) and the lambing rate (eCG, 9/30 vs. no eCG, 20/28; $p=0.002)$. In conclusion, treatment with eCG 11 days after AI reduced pregnancy and lambing rates in Creole ewes.
\end{abstract}

Keywords | Birth rate, eCG, Gestation rate, Ovine, Sheep

Received | May 02, 2021; Accepted | June 02, 2021; Published | September 10, 2021

*Correspondence | Ulises S. Quispe-Gutiérrez, Faculty of Veterinary Medicine and Zootechnics, Micaela Bastidas National University of Apurimac, Tamburco, Abancay, Apurímac, Perú. C.P. 03000; Email: usquispe@unamba.edu.pe

Citation | Quispe-Gutiérrez US, Rangel-Santos R, Ayala-Mariano SA, Berndtson JL (2021). Equine chorionic gonadotropin treatment 11 days after artificial insemination reduces pregnancy and lambing rates in creole ewes. Adv. Anim. Vet. Sci. 9(10): 1710-1717.

DOI | http://dx.doi.org/10.17582/journal.aavs/2021/9.10.1710.1717

ISSN (Online) | 2307-8316; ISSN (Print) | 2309-3331

Copyright $(2021$ Quispe-Gutiérrez et al. This is an open access article distributed under the Creative Commons Attribution License, which permits unrestricted use, distribution, and reproduction in any medium, provided the original work is properly cited.

\section{INTRODUCTION}

$\mathrm{I}^{n+\infty}$ sheep production, the main objective is to increase pregnancy rate to improve reproductive efficiency. Approximately 20 to $50 \%$ of embryonic losses in ewes occurs during the early embryonic period (García-Pintos and Menchaca, 2018; Juengel et al., 2020), possibly due to poor luteal function and low progesterone production (de Brun et al., 2016). Both these factors are crucial for maternal recognition of pregnancy in ewes, a critical step for establishment and maintenance of pregnancy
(O'Connell et al., 2016; Van-Lier et al., 2017; Kamil, 2019). Conventionally eCG is administered to ewes upon removal of progesterone impregnanted vaginal sponges, which are kept in place for 6 to 14 days to synchronize heat and superovulation (Atalla, 2018; Samartzi et al., 2020). Recently, eCG administration after AI to improve pregnancy has been experimented on in ewes. However, in ewes there is little evidence that $\mathrm{eCG}$ administration after AI in fact improves pregnancy rates (García-Pintos and Menchaca, 2016, 2018). Although, there is more evidence of pregnancy improvement in cattle (Bartolome et al., 
2012; Wecker et al., 2012; Núñez-Olivera et al., 2018) and in rabbits (Hashem and Aboul-ezz, 2018).

Luteal function and progesterone production are essential for embryonic establishment during the early developmental period. There is a relationship between increased serum progesterone concentration, larger corpus luteum size, and better luteal function (Hashem and Sallam, 2020). When luteal function improves, the progesterone concentration increases in ewes (Vergani et al., 2020). In goats, progesterone production minimizes pregnancy loss without affecting embryonic viability (Hashem et al., 2015). The administration of eCG on day 10 after ovulation improves luteal function, increases progesterone levels in ewes (García-Pintos and Menchaca, 2016), and probably helps the establishment of pregnancy during the first month of gestation (García-Pintos and Menchaca, 2018). The eCG as a luteotrophic agent, post -ovulation, could be an alternative to improve pregnancy rates in anestrous beef cows (Núñez-Olivera et al., 2018). These evidences shows a positive effect of eCG on increasing progesterone concentrations; however, studies using eCG after insemination are minimal and the effects on pregnancy in ewes are still unclear.

One of the strategies to reduce early pregnancy losses in ewes would be to improve the function of the corpus luteum to stimulate the production of sufficient progesterone. eCG shows biological activities similar to those produced by luteinizing hormone (LH) and follicle stimulating hormone (FSH) (Murphy, 2012). These pituitary hormones, mainly LH, are essential for the growth and maintenance of the corpus luteum (Wiltbank et al., 2012). The eCG modulates the gene expression of the corpus luteum and participates in the synthesis of lipids and progesterone (Fátima et al., 2012b). The positive impact of eCG on pregnancy is likely due to the ability of eCG to induce changes at the molecular, cellular and tissue levels related to the corpus luteum (Fátima et al., 2012a) which promotes the production of progesterone (Núñez-Olivera et al., 2018). When eCG is administered after ovulation, it improves the competent corpus luteum in beef heifers (Núñez-Olivera et al., 2020), increases progesterone levels in ewes (García-Pintos and Menchaca, 2016) with different pregnancy rates between cross breed and Merino ewes (García-Pintos and Menchaca 2018). These initial results require further investigation in different conditions and genetic groups of ewes to see the effects of eCG after insemination.

The objective of the present study was to evaluate the administration of eCG 11 days after insemination on pregnancy and parturition rates in nulliparous and multiparous Creole ewes.

\section{MATERIALS AND METHODS}

\section{LOCATION AND ANIMALS}

The study was conducted at the Experimental Farm of the Chapingo Autonomous University, State of Mexico $\left(19^{\circ} 29^{\prime} 44^{\prime \prime} \mathrm{N} 98^{\circ} 52^{\prime} 15^{\prime \prime} \mathrm{W}\right)$. Nulliparous and multiparous ewes were randomly maintained in pens containing feeders and drinking troughs. A closed environment was used for insemination and ultrasonography. Two days before the onset of heat synchronization until one day before AI ewes received flush feeding. The flushing diet consisted of corn silage (35\%) and concentrate (65\%) [Crude Protein 14\% and Metabolizable Energy 2.68 $\mathrm{Mcal} \mathrm{kg}^{-1}$ of MS]. For two weeks after AI, the diet was reduced (5\% concentrate and 95\% corn silage) and subsequently followed by a balanced diet according to the NRC recommendation for pregnant ewes (NRC, 1985). At the beginning of the first day of flushing, the body condition score of the nulliparous and multiparous (2.6 \pm 1.5 births) ewes were $3.0 \pm 0.1$ and $3.3 \pm 0.1$ (scale 1 to 5 ; where $1=$ emaciated, and $5=$ obese; Russel et al., 1969) with body weights of $36.2 \pm 1.2$ and $45.3 \pm 1.6$ $\mathrm{kg}$, respectively. All the procedures were approved by the Animal Use Committee, Animal Science Department, Chapingo Autonomous University, Mexico.

\section{EXPERIMENTAL DESIGN}

Estrous synchronization for all ewes was performed with intravaginal sponges impregnated with $20 \mathrm{mg}$ of chronolone (Chronogest ${ }^{\circledR}$ CR, MSD, Animal Health, Mexico) for 12 days. Estrous detection was carried out with Creole rams equipped with an apron, for 30 min every $6 \mathrm{~h}, 24 \mathrm{~h}$ after intravaginal sponge removal until $96 \mathrm{~h}$. AI was performed using conventional laparoscopy (Evans and Maxwell, 1987) $18 \mathrm{~h}$ after heat detection. Semen was collected with an artificial vagina $1 \mathrm{~h}$ before insemination (Aké-Villanueva et al., 2017). Sperm motility was assessed as described by Evans and Maxwell (Evans and Maxwell, 1987), while sperm concentration was estimated using a hemocytometer (Kasimanickam et al., 2006). The sample was then diluted with $20 \%$ Triladyl $^{\circledR}$ (Minitube, Germany), 20\% egg yolk and 60\% double distilled water. Finally, each ewe was inseminated with $100 \times 10^{6}$ sperm, with half the dose placed into each uterine horn. The semen was obtained from a single Creole ram of known fertility, using ejaculates with sperm mass motility $(0-5) \geq$ 4 , concentration $\geq 2500 \times 10^{6} \mathrm{~mL}^{-1}$ and a maximum of $10 \%$ abnormalities (Evans and Maxwell, 1987; Gil et al., 2003).

Fifty-eight clinically healthy Creole ewes were randomly assigned into groups, according to maternal physiological status (number of lambing) and administered treatment: eCG (nulliparous, $\mathrm{n}=14$ and multiparous, $\mathrm{n}=16$ ) or no eCG (nulliparous, $n=13$ and multiparous, $n=15$ ). The day of insemination was considered day 0. eCG (Folligon ${ }^{\circledR}$, 
MSD, Animal Health, Mexico) 330 IU was administered IM to ewes in the eCG treatment group, the other ewes received sodium chloride as a placebo, 11 days after insemination. Blood samples were taken on days 11 and 15 , to determine serum concentrations of estradiol and progesterone. On day 15 , large follicle (large $\geq 5 \mathrm{~mm}$, small $\leq 4 \mathrm{~mm}$ in diameter; adapted from Menchaca and Rubianes (Menchaca and Rubianes, 2004) and large corpus luteum (large $\geq 10 \mathrm{~mm}$, small $\leq 9 \mathrm{~mm}$ in diameter; adapted from Allam et al. (2015) were evaluated by ultrasound; large follicle or large corpus luteum were classified into two categories as present or absent according to reference sizes. Also, on day 15, turgid uterus was subjectively evaluated using the laparoscopic lens, adapting to the description of Graff (2010) and Juengel et al. (2016), it was considered turgid uterus when it presented the maximum or firm tone with a color tending to pink; on the contrary, if the uterus was flaccid with minimal tone, it was considered a nonturgid uterus. At day 35, pregnancy was diagnosed through transrectal ultrasonography (ProSound 2, Aloka, 7.5 MHz linear transducer, Aloka) (Figure 1). Finally, the lambing was recorded.

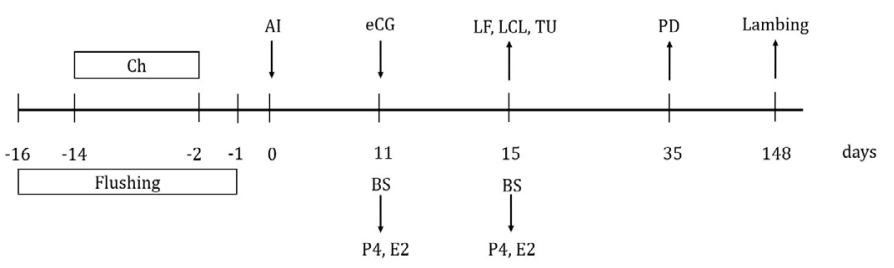

Figure 1: Schematic diagram of equine chorionic gonadotropin (eCG) treatment after insemination in Creole ewes. $\mathrm{Ch}=20 \mathrm{mg}$ chronolone in intravaginal sponge; $\mathrm{AI}=$ artificial insemination; $\mathrm{eCG}=$ application of $330 \mathrm{IU}$ of equine chorionic gonadotropin to the group of ewes that received eCG; $\mathrm{BS}=$ blood sample; $\mathrm{P} 4=$ progesterone concentration; $\mathrm{E} 2=$ estradiol concentration; $\mathrm{LF}=$ large follicles evaluation; $\mathrm{LCL}=$ large corpus luteum evaluation; $\mathrm{TU}=$ turgid uterus evaluation; $\mathrm{PD}=$ pregnancy diagnosis .

The reproductive performance of ewes was evaluated by calculating the following variables: pregnancy rate $=$ (ewes pregnant on day 35/total ewes inseminated) $x 100$; lambing rate $=$ (number of ewes lambing/total ewes inseminated) $\mathrm{x}$ 100.

\section{SERUM DETERMinATIONS OF PROGESTERONE AND} ESTRADIOL

Blood was collected from 40 ewes total, 10 in each group: eCG nulliparous, eCG multiparous, no eCG nulliparous, and no eCG multiparous. Blood was collected by jugular venipuncture in vacutainer tubes of $10 \mathrm{~mL}$, on days 11 and 15 after AI. Blood was immediately centrifuged at 1500 $\mathrm{x} \mathrm{g}$ for $20 \mathrm{~min}$ and serum was stored in cryovials at -20 ${ }^{\circ} \mathrm{C}$, until analysis. The serum progesterone concentration was evaluated by solid phase radioimmunoassay (Coat-ACount, Siemens, CA, USA) with a test sensitivity of 0.02 $\mathrm{ng} \mathrm{mL} \mathrm{mL}^{-1}$ and coefficient of variation of $2.80 \%$. The estradiol concentration was determined by an enzyme immunoassay, with a polyclonal antibody (R4972; C. Munro, University of California, Davis, USA) and an estradiol conjugate (17B-3 hemisuccinate-HRP), with a test sensitivity of $0.40 \mathrm{pg} \mathrm{mL}-1$ and a coefficient of variation of $5.57 \%$.

\section{STATISTICAL ANALYSIS}

Statistical analyses were performed with the SAS 9.3 statistical package (SAS, 2011). For continuous response variables: Progesterone concentration and estradiol concentration; the statistical model included the effects of treatment (eCG, No eCG), maternal physiological status (nulliparous, multiparous), and their interactions. Before analysis, normality and homogeneity of variances were checked by the Shapiro-Wilk and Levene tests, then analyzed by two-way analysis of variance. Means were compared among groups using Bonferroni test. For categorical response variables: presence of large follicle, a turgid uterus, a large corpus luteum, pregnancy rate and lambing rate; the statistical model considered the effects of treatment, maternal physiological status, and their interaction; these were removed from the model if they were non-significant. The data were analyzed with logistic regression; the stepwise method was used to generate the model. In addition, the Hosmer and Lemeshow tests were performed for the goodness of fit of the model. Differences were considered significant when $p$ value was less than 0.05 .

\section{RESULTS AND DISCUSSION}

\section{LARGE FOLLICLE, TURGID UTERUS AND LARGE CORPUS} LUTEUM

The effects of treatment with eCG 11 days after AI in Creole ewes are shown in Table 1 . The eCG affected the number of large follicles $(p=0.041)$. A higher percentage of ewes that received eCG had large follicles (11/30) than those who did not receive eCG (4/28) [odds ratio $(\mathrm{OR})=3.88 ; 95 \%$ confidence interval $(\mathrm{CI})=1.06$ to 14.28$]$. The eCG treatment also influenced the percentage of ewes with a turgid uterus $(p=0.005)$. More ewes treated with eCG had a turgid uterus (13/30) than those who did not receive eCG treatment $(1 / 28)[\mathrm{OR}=20.65 ; 95 \% \mathrm{CI}=2.47$ to 172.46$]$.

The large corpus luteum were influenced by eCG treatment $(p=0.013)$. A higher percentage of ewes that received eCG had large corpus luteum (15/30) than those who did not receive eCG $(6 / 28)$ [OR=4.59; 95\% CI=1.38 to 15.28]. Maternal physiological status did not affect the presence of a large corpus luteum $(\mathrm{p}=0.185)$, a turgid uterus $(\mathrm{p}=0.745)$ 
or large follicles $(\mathrm{p}=0.686)$. The interaction between maternal physiological status and eCG treatment for large follicles, turgid uterus and large corpus luteum were not significant.

\section{Pregnancy Rate and lambing Rate}

The effect of eCG administration 11 days after AI on pregnancy at 35 days and lambing are shown in Table 2. Ewes that received eCG had a lower $(\mathrm{p}=0.003)$ pregnancy rate $(13 / 30)$ than those did not receive eCG $(23 / 28)$ $[\mathrm{OR}=0.17 ; 95 \% \mathrm{CI}=0.05$ to 0.58$]$. Non-significant differences $(p=0.305)$ were observed in pregnancy rates between nulliparous and multiparous ewes.

Table 1: Percentage of large follicles, turgid uterus and large corpus luteum in Creole ewes treated with equine chorionic gonadotropin (eCG), 11 days after insemination.

\begin{tabular}{lrrrrrr} 
& \multicolumn{2}{c}{$\begin{array}{c}\text { Large follicles* } \\
\end{array}$} & $\begin{array}{c}\text { Turgid } \\
\text { uterus* }\end{array}$ & \multicolumn{2}{c}{$\begin{array}{c}\text { Large corpus } \\
\text { luteum* }\end{array}$} \\
Nulliparous & 29.6 & $(8 / 27)^{\mathrm{a}}$ & 25.9 & $(7 / 27)^{\mathrm{a}}$ & 29.6 & $(8 / 27)^{\mathrm{a}}$ \\
Multiparous & 22.6 & $(7 / 31)^{\mathrm{a}}$ & 22.6 & $(7 / 31)^{\mathrm{a}}$ & 41.9 & $(13 / 31)^{\mathrm{a}}$ \\
p value & & 0.686 & & 0.745 & & 0.185 \\
Treatment & & & & & & \\
eCG & 36.7 & $(11 / 30)^{\mathrm{a}}$ & 43.3 & $(13 / 30)^{\mathrm{a}}$ & 50.0 & $(15 / 30)^{\mathrm{a}}$ \\
No eCG & 14.3 & $(4 / 28)^{\mathrm{b}}$ & 3.6 & $(1 / 28)^{\mathrm{b}}$ & 21.4 & $(6 / 28)^{\mathrm{b}}$ \\
p value & & 0.041 & & 0.005 & & 0.013
\end{tabular}

Within a column, different superscripts differ significantly ( $\mathrm{p}$ $\leq 0.05$ ). "Evaluated at four days (15 day) after eCG treatment (large follicles: $\geq 5 \mathrm{~mm}$ in diameter, large corpus luteum: $\geq 10$ $\mathrm{mm}$ in diameter, turgid uterus present or absent, respectively).

Table 2: Percentage of pregnancy and lambing rates in Creole ewes treated with equine chorionic gonadotropin (eCG) 11 days after insemination.

\begin{tabular}{|c|c|c|c|c|}
\hline & \multicolumn{2}{|c|}{ Pregnancy rate } & \multicolumn{2}{|c|}{ Lambing rate } \\
\hline & $\%$ & $\mathbf{n}$ & $\%$ & $\mathrm{n}$ \\
\hline \multicolumn{5}{|c|}{ Maternal physiological status } \\
\hline Nulliparous & 55.6 & $(15 / 27)^{\mathrm{a}}$ & 37.0 & $(10 / 27)^{a}$ \\
\hline Multiparous & 67.7 & $(21 / 31)^{\mathrm{a}}$ & 61.3 & $(19 / 31)^{\mathrm{b}}$ \\
\hline $\mathrm{p}$ value & & 0.305 & & 0.042 \\
\hline \multicolumn{5}{|l|}{ Treatment } \\
\hline eCG & 43.3 & $(13 / 30)^{a}$ & 30.0 & $(9 / 30)^{a}$ \\
\hline No eCG & 82.1 & $(23 / 28)^{b}$ & 71.4 & $(20 / 28)^{b}$ \\
\hline $\mathrm{p}$ value & & 0.003 & & 0.002 \\
\hline
\end{tabular}

Within a column, different superscripts differ significantly ( $\mathrm{p}$ $\leq 0.05$ ). Pregnancy rate $=$ (ewes pregnant on day $35 /$ total ewes inseminated) x 100. Evaluated at 35 days post-insemination. Lambing rate $=$ (Number of ewes lambing/total ewes inseminated) $\mathrm{x} 100$.
Lambing rate was influenced by eCG treatment $(\mathrm{p}=0.002)$, ewes that received eCG presented lower lambing rate $(9 / 30)$ than those did not receive eCG (20/28) [OR=0.13; $95 \% \mathrm{CI}=0.03$ to 0.48$]$. The multiparous ewes had a higher $(\mathrm{p}=0.042)$ lambing rate $(19 / 31)$ than nulliparous ewes (9/30) [OR=4.13; 95\% CI=1.60 to 16.17]. The interaction was not significant between maternal physiological status and treatment for lambing rates.

\section{ESTRADIOL AND PROGESTERONE CONCENTRATIONS}

The results of eCG treatment on serum estradiol and progesterone concentrations are shown in Table 3. No interaction was found between maternal physiological state and eCG treatment in serum estradiol concentration $(p=0.314)$ on day 15 . Between nulliparous and multiparous ewes, serum estrogen concentrations were similar on day $11(\mathrm{p}=0.412)$ and day $15(\mathrm{p}=0.365)$. On day 15, a higher serum concentration of $17 ß$ estradiol $(p=0.0001)$ was obtained in sheep treated with eCG compared to untreated $\left(10.43 \pm 0.42\right.$ vs. $\left.6.24 \pm 0.25 \mathrm{pg} \mathrm{mL}^{-1}\right)$. Likewise, there was no interaction between maternal physiological state and eCG treatment on serum progesterone concentration $(\mathrm{p}=0.125)$. Maternal physiological status did not affect serum progesterone concentration on day $11(\mathrm{p}=0.324)$ or on day $15(\mathrm{p}=0.434)$. On day 15 , a higher $(\mathrm{p}=0.0001)$ serum progesterone concentration was found in the group of eCG treated ewes compared to those did not receive eCG $\left(8.22 \pm 0.21\right.$ vs. $\left.5.28 \pm 0.19 \mathrm{ng} \mathrm{mL}^{-1}\right)$.

Table 3: Serum estradiol and progesterone concentrations $(\mathrm{Mean} \pm \mathrm{SEM})$ in Creole ewes treated with equine chorionic gonadotropin (eCG), 11 days after insemination.

\begin{tabular}{|c|c|c|c|c|c|}
\hline & \multirow[t]{2}{*}{$\mathbf{n}$} & \multicolumn{2}{|c|}{$\begin{array}{l}\text { Estradiol-17 } \\
\quad\left(\mathrm{pg} \mathrm{mL} \mathrm{mL}^{-1}\right)\end{array}$} & \multicolumn{2}{|c|}{$\begin{array}{l}\text { Progesterone } \\
\left(\text { (ng } \mathrm{mL}^{-1}\right)\end{array}$} \\
\hline & & Day 11 & Day 15 & Day 11 & Day 15 \\
\hline \multicolumn{6}{|c|}{ Maternal physiological status } \\
\hline Nulliparous & 20 & $5.71 \pm 0.24^{\mathrm{a}}$ & $8.56 \pm 0.65^{\mathrm{a}}$ & $4.19 \pm 0.13^{\mathrm{a}}$ & $6.86 \pm 0.44^{\mathrm{a}}$ \\
\hline Multiparous & 20 & $5.99 \pm 0.22^{\mathrm{a}}$ & $8.11 \pm 0.52^{\mathrm{a}}$ & $4.37 \pm 0.13^{\mathrm{a}}$ & $6.64 \pm 0.34^{a}$ \\
\hline $\mathrm{p}$ value & & 0.412 & 0.365 & 0.324 & 0.434 \\
\hline \multicolumn{6}{|l|}{ Treatment } \\
\hline eCG & 20 & $5.82 \pm 0.21^{\mathrm{a}}$ & $10.43 \pm 0.42^{\mathrm{a}}$ & $4.13 \pm 0.13^{\mathrm{a}}$ & $8.22 \pm 0.21^{\mathrm{a}}$ \\
\hline No eCG & 20 & $5.88 \pm 0.25^{\mathrm{a}}$ & $6.24 \pm 0.25^{b}$ & $4.42 \pm 0.13^{\mathrm{a}}$ & $5.28 \pm 0.19^{b}$ \\
\hline $\mathrm{p}$ value & & 0.862 & 0.0001 & 0.116 & 0.0001 \\
\hline
\end{tabular}

Within a column, different superscripts differ significantly $(\mathrm{p} \leq$ 0.05). Day zero=day of artificial insemination.

The hypothesis of this study was that the administration of eCG 11 days after insemination would increase the number of large corpora lutea, the concentration of serum progesterone and improve the pregnancy and lambing rates in Creole ewes. Treatment with eCG modulates the expression of several genes in the corpus luteum that are involved in lipid biosynthesis and progesterone production 
(Fátima et al., 2012b). The positive effects of eCG on pregnancy are likely due to increased functionality of the corpus luteum for progesterone synthesis (Fátima et al., 2012a), which is essential for the establishment and maintenance of pregnancy (Bartolome etal.,2012;Wiltbank et al., 2012). Elevated progesterone concentrations during embryonic development are associated with improved early conceptus development, increased production of interferon tau (IFN- $\tau$ ), and high pregnancy rates (Hashem et al., 2015; Lonergan and Sánchez 2020. The use of post-ovulation eCG as a luteotrophic agent could be an alternative to improve pregnancy rates in cattle (NúñezOlivera et al., 2020).

In the present study, the administration of eCG 11 days after insemination resulted in higher numbers of large corpora lutea and a higher concentration of serum progesterone in eCG-treated ewes compared to untreated ones 4 days after administration. These results are supported by GarcíaPintos and Menchaca (2016) who, when administering eCG on day 10 after insemination of the ewes, found increases the size of the corpus luteum and progesterone levels. Also the administering eCG on day 12 after mating of the ewes, increased the serum concentrations of progesterone compared to those treated with $\mathrm{GnRH}$ (Allam et al., 2015). Treatment with eCG on day 14 after artificial insemination at a fixed time increases the area of the corpus luteum, improving serum concentrations of progesterone in anestrous beef cows (Núñez-Olivera et al., 2018). In rabbits, the administration of eCG 7 days after insemination increased the number of corpora lutea and the serum progesterone concentration (Hashem and Aboul-ezz, 2018). This shows that increases in serum progesterone concentration are related to increases in the number of corpus luteum and improvements in luteal function (Hashem and Sallam, 2020). The greater number of large corpora lutea found in the present study is probably attributed to eCG activating luteotropic mechanisms. Consequently, the progesterone concentration would increase. The luteotrophic mechanisms of the effect of eCG after insemination in cattle are still unclear, and therefore warrant further investigation (Núñez-Olivera et al., 2018).

The administration of eCG 11 days after insemination decreased the pregnancy rate at 35 days and the lambing rate in Creole ewes in the present experiment. In other studies, the administration of eCG after insemination did not affect the pregnancy rate in ewes. When administering eCG after insemination, they found different pregnancy rates at 30 days, $35.0 \%$ (eCG 5 days), 33.3\% (eCG 10 days) in crossbred ewes; $50.5 \%$ (eCG 5 days) in Merino ewes (García-Pintos and Menchaca, 2018); 46.4\% with eCG 12 days post-mating in Harri ewes (Allam et al., 2015). Although these pregnancy rates are similar to the $43.3 \%$ pregnancy rate found in the eCG group, where pregnancy was reduced in the present study. In other species, the administration of eCG after insemination improves the pregnancy rate in bovines (Bartolome et al., 2012; Wecker et al., 2012; Núñez-Olivera et al., 2018) and in rabbits (Hashem and Aboul-ezz, 2018). Previous studies showed that the increase in the concentration of circulating progesterone, during the first week after ovulation, effectively stimulates the growth of the embryo and the secretion of IFN- $\tau$, thus favoring the maintenance of pregnancy, leading to higher rates of pregnancy (O'Hara et al., 2016; Núñez-Olivera et al., 2018; Lonergan and Sánchez, 2020). On the other hand, the administration of eCG after insemination, resulted in a lower pregnancy rate in crossbred ewes than in Merino, these received different driving conditions; therefore, other factors, such as genetics and environment, could play an important role (GarcíaPintos and Menchaca, 2018). In the present study, there was a greater concentration of serum progesterone in the group of ewes that received eCG, however this increase was insufficient to maintain early gestation and improve the lambing rate. The positive effect of the administration of eCG after insemination on the pregnancy rate in ewes appears to be different than in cattle, likely due to the dose of eCG used, which would require adjustment; the genetic group and the management conditions also seem to influence the gestation rate.

In the present study, the reduction in the pregnancy rate and the lambing rate would have a sequential relationship with the number of large follicles, high estradiol concentration, and the number of turgid uteri found in greater quantity in the group of ewes that received eCG after insemination. The administration of eCG on day 5 or day 10 after insemination promotes the growth of large follicles, which can cause increased estradiol production with negative effects on embryo survival and/or luteal function in ewes (GarcíaPintos and Menchaca, 2016). In cows, the administration of eCG after insemination increased the number of large follicles (Wecker et al., 2012) and increased the serum concentrations of estradiol-17 $\beta$ (Núñez-Olivera et al., 2018). A positive relationship exists between the eCG dose and the number of dominant follicles; therefore, the serum concentrations of estradiol increase in a dose-dependent manner (O'Hara et al., 2016). The increase in follicular size is attributed to the fact that eCG has an affinity for the LH and FSH receptors located in the follicles (Murphy, 2012). This eCG performs functions similar to FSH and LH (Beracochea et al., 2020). In the present study, the formation of a greater number of follicles would have caused an increase in estradiol concentration; consequently, an increase in the number of turgid uteri. During estrus, the concentration of estrogens increases as the follicular size increases (Mahmoud and Senosy, 2019; Figueira et al., 2020; Hemati et al., 2020); and the expression of estrogen receptors increases in the endometrium of ewes 
(Duan et al., 2019). In this periovulatory period, uterine tone increases, stimulated by estrogens (Bonafos et al., 1995), the uterus is turgid or toning up (Fesseha and Degu, 2020). In the present study, the increase in estradiol concentration probably triggered luteolysis in ewes that received eCG, which induced early embryonic loss; likely for this reason, the pregnancy rate and the lambing rate decreased. García-Pintos and Menchaca (2018) mention that post-insemination eCG treatment would not be sufficient in establishing pregnancy in ewes during the second month. It is well established that estradiol binds to the estrogen receptor and results in the synthesis and insertion of oxytocin receptors in the endometrium, activating the synthesis and pulsatile release of PGF $2 \alpha$ to initiate luteolysis (Weems et al., 2014; Hansen et al., 2017; Li et al., 2020). Finally, it is not yet clear how the administration of eCG after insemination acts on follicular dynamics in ewes; therefore, it requires further studies aimed at adjusting the dose, time of administration, and the molecular effects on the reproductive tract. Later, eCG could become an alternative to improve the pregnancy rate in ewes.

\section{CONCLUSIONS AND RECOMMENDATIONS}

In conclusion, treatment with eCG, 11 days after artificial insemination in Creole ewes, reduced pregnancy and lambing rates. The amount of large follicles, turgid uteruses, and serum estradiol concentrations were increased on day 15 after AI in eCG treated ewes. Additional research is needed to analyze breeding performance of Creole ewes using eCG after AI.

\section{ACKNOWLEDGMENTS}

Department of Experimental Farm of the DEIS in Zootechnics, Reproduction Laboratory of the Chapingo Autonomous University is thanked for providing materials and animals. We are also thankful to the Endocrinology Laboratory of the Faculty of Veterinary Medicine and Zootechnics of the National Autonomous University of Mexico, for allowing hormonal analyzes; to the SREMexico, and to the professors R Rodríguez de Lara, JG García-Muñiz, C Gutiérrez and JG Rivera-Martínez (R.I.P.) for their unconditional support.

\section{AUTHOR'S CONTRIBUTION}

USQG and RRS conceived, designed, executed, analyzed the data and wrote the manuscript. SAAM executed the experiment. JLB interpretation of results, and writing of the manuscript.

\section{NOVELTY STATEMENT}

The eCG administered 11 days post-insemination causes turgid uteruses at the same time increase in estradiol-17 $B$ on day 15 in Creole ewes. The eCG administered 11 days post-insemination produces pregnancy loss in Creole ewes.

\section{CONFLICT OF INTEREST}

The authors have declared no conflict of interest.

\section{REFERENCES}

-Aké-Villanueva JR, Aké-López JR, Segura-Correa JC, Magaña-Monforte JG, Aké-Villanueva NY (2017). Factors affecting conception rate of hair ewes after laparoscopic insemination with chilled semen under tropical conditions. Small Rumin. Res., 153: 114-117. https://doi.org/10.1016/j. smallrumres.2017.06.006

-Allam AM, El-Zarkouny SZ, Elshahawy II, Nagadi SA, Kesler DJ (2015). Effects of post-mating treatments with gonadotropin-releasing hormone and equine chorionic gonadotropin on reproductive efficiency of Harri ewes in tropical regions. Small Rumin. Res., 132: 55-59. http:// linkinghub.elsevier.com/retrieve/pii/S0921448815300730 https://doi.org/10.1016/j.smallrumres.2015.10.002

-Atalla H (2018). The effects of different doses of equine chorionic gonadotropin on induction of estrus and reproductive patterns in Assaf ewes out of breeding season. Int. J. Curr. Microbiol. Appl. Sci., 7(6): 2078-2085. https:// doi.org/10.20546/ijcmas.2018.706.245

-Bartolome JA, Wallace SP, de la Sota RL, Thatcher WW (2012). The effect of administering equine chorionic gonadotropin (eCG) and human chorionic gonadotropin (hCG) post artificial insemination on fertility of lactating dairy cows. Theriogenology, 78(5): 1110-1116. https://doi. org/10.1016/j.theriogenology.2012.05.006

-Beracochea F, Viera MN, Santiago-Moreno J, Ungerfeld R (2020). Treatment of male goats with equine chorionic gonadotrophin during the non-breeding season does not affect their sperm characteristics during the subsequent breeding season. Trop. Anim. Hlth. Prod., 52(1): 211-215. https://doi.org/10.1007/s11250-019-02004-y

- Bonafos LD, Kot K, Ginther OJ (1995). Physical characteristics of the uterus during the bovine estrous cycle and early pregnancy. Theriogenology, 43(4): 713-721. https://doi. org/10.1016/0093-691X(95)00014-Y

- de Brun V, Meikle A, Fernández-Foren A, Forcada F, Palacín I, Menchaca A, Sosa C, Abecia JA (2016). Failure to establish and maintain a pregnancy in undernourished recipient ewes is associated with a poor endocrine milieu in the early luteal phase. Anim. Reprod. Sci., 173: 80-86. https://doi. org/10.1016/j.anireprosci.2016.08.016

-Duan H, Xiao L, Hu J, Zhang Y, Zhao X, Ge W, Jiang Y, Song L, Yang S, Luo W (2019). Expression of oestrogen receptor, androgen receptor and progesterone nuclear receptor in sheep uterus during the oestrous cycle. Reprod. Domest. Anim., 54(10): 1305-1312. https://doi.org/10.1111/ rda. 13489

- Evans G and Maxwell W (1987). Salamon's artificial insemination of sheep and goats. $2^{\text {nd }}$ ed. Butterworths, Sydney. pp. 194. 
- Fátima LA, Baruselli PS, Gimenes LU, Binelli M, Renna FP, Murphy BD, Papa PC (2012a). Global gene expression in the bovine corpus luteum is altered after stimulatory and superovulatory treatments. Reprod. Fertil. Dev., 25: 9981011. https://doi.org/10.1071/RD12155

- Fátima LA, Binelli M, Baruselli PS, Neto Bonfim AP, Papa PC (2012b). Angiogenic and steroidogenic responses of the corpus luteum after superovulatory and stimulatory treatments using eCG and FSH. Anim. Reprod., 9: 273-280. https://www.animal-reproduction.org/ article/5b5a6058f7783717068b46e6

- Fesseha H, Degu T (2020). Estrus detection, estrus synchronization in cattle and it's economic importance. Int. J. Vet. Res., 3(1): 1001. https://medcarescience.org/ international-journal-of-veterinary-research-archive.html

- Figueira LM, Alves NG, Souza-Fabjan JMG, Oliveira MEF, Lima RR, Souza GN, Fonseca JF (2020). Preovulatory follicular dynamics, ovulatory response and embryo yield in Lacaune ewes subjected to synchronous estrus induction protocols and non-surgical embryo recovery. Theriogenology, 145: 238-246. https://doi.org/10.1016/j. theriogenology.2019.11.004

- García-Pintos C, Menchaca A (2016). Luteal response and follicular dynamics induced with equine chorionic gonadotropin (eCG) administration after insemination in sheep. Small Rumin. Res., 136: 202-207. https://doi. org/10.1016/j.smallrumres.2016.02.006

- García-Pintos C, Menchaca A (2018). Pregnancy establishment and maintenance after the administration of equine chorionic gonadotropin (eCG) associated or not with gonadotropinreleasing hormone $(\mathrm{GnRH})$ after insemination in sheep. Anim. Prod. Sci., 58(10): 1802-1806. https://doi. org/10.1071/AN16489

- Gil J, Rodriguez-Irazoqui M, Lundeheim N, Söderquist L, Rodríguez-Martínez H (2003). Fertility of ram semen frozen in Bioexcell ${ }^{\circledR}$ and used for cervical artificial insemination. Theriogenology, 59(5-6): 1157-1170. https:// doi.org/10.1016/S0093-691X(02)01178-0

- Graaf S (2010). Reproduction. In: Cottle D (ed). International sheep and wool handbook. $1^{\text {st }}$ ed. Nottingham University Press, Nottingham, United Kingdom. Chapter 9: 189-222. https://doi.org/10.7313/UPO9781907284595.011

- Hansen TR, Bott R, Romero J, Antoniazzi A, Davis JS (2017). Corpus luteum and early pregnancy in ruminants. In: Meidan R (ed). The life cycle of the corpus luteum. $1^{\text {st }}$ ed. Springer Int. Publ., Switzerland. 11: 205-225. https://doi. org/10.1007/978-3-319-43238-0_11

- Hashem NM, Aboul-ezz ZR (2018). Effects of a single administration of different gonadotropins on day 7 postinsemination on pregnancy outcomes of rabbit does. Theriogenology, 105: 1-6. https://doi.org/10.1016/j. theriogenology.2017.09.006

-Hashem NM, El-Azrak KM, Nour El-Din ANM, Taha TA, Salem MH (2015). Effect of GnRH treatment on ovarian activity and reproductive performance of low-prolific Rahmani ewes. Theriogenology, 83(2): 192-198. https://doi. org/10.1016/j.theriogenology.2014.09.016

-Hashem NM, Sallam SM (2020). Reproductive performance of goats treated with free gonadorelin or nanoconjugated gonadorelin at estrus. Domest. Anim. Endocrinol., 71: 106390. https://doi.org/10.1016/j.domaniend.2019.106390

- Hemati M, Khodaei-Motlagh M, Yahyae M (2020). Effects of increased exposure time to $\mathrm{eCG}$ on reproductive performance in estrus-synchronized Farahani ewes. J. Livest. Sci. Technol., 8(2): 15-20.

-Juengel JL, French MC, O'Connell AR, Edwards SJ, Haldar A, Brauning R, Farquhar PA, Dodds KG, Galloway SM, Johnstone PD, Davis GH (2016). Mutations in the leptin receptor gene associated with delayed onset of puberty are also associated with decreased ovulation and lambing rates in prolific Davisdale sheep. Reprod. Fertil. Dev., 28(9): 1318-1325. https://doi.org/10.1071/RD14382

-Juengel JL, Quirke LD, Hyslop K, Meenken ED, Peers-Adams J, Smith P, Edwards SJ (2020). Association of fertility with group mating behavior in ewes. Anim. Reprod. Sci., 216: 106359. https://doi.org/10.1016/j.anireprosci.2020.106359

-Kamil AM(2019).Progesterone level of lactating ewes influenced by parity order, type of lambing and lambs sex. Adv. Anim. Vet. Sci., 7(4): 295-300. https://doi.org/10.17582/journal. aavs/2019/7.4.295.300

- Kasimanickam R, Pelzer KD, Kasimanickam V, Swecker WS, Thatcher CD (2006). Association of classical semen parameters, sperm DNA fragmentation index, lipid peroxidation and antioxidant enzymatic activity of semen in ram-lambs. Theriogenology, 65(7): 1407-1421. https://doi. org/10.1016/j.theriogenology.2005.05.056

- Li Q, Zhang S, Mao W, Fu C, Shen Y, Wang Y, Liu B, Cao J (2020). 17 $\beta$-estradiol regulates prostaglandin E2 and F2 $\alpha$ synthesis and function in endometrial explants of cattle. Anim. Reprod. Sci., 216: 106466. https://doi.org/10.1016/j. anireprosci.2020.106466

-Lonergan P, Sánchez JM (2020). Symposium review: Progesterone effects on early embryo development in cattle. J. Dairy Sci., 103(9): 8698-8707. https://doi.org/10.3168/ jds.2020-18583

- Mahmoud GB, Senosy W (2019). Effect of synchronizing estrus with intravaginal progestagen sponges or prostaglandin $\mathrm{F} 2 \alpha$ on estrus behavior, ovarian structures, estradiol-17 $\beta$ and progesterone levels of Ossimi ewes under subtropics. Egypt J. Sheep Goat Sci., 14: 53-60.

- Menchaca A, Rubianes E (2004). New treatments associated with timed artificial insemination in small ruminants. Reprod. Fertil. Dev., 16(4): 403-413. https://doi. org/10.1071/RD04037

- Murphy BD (2012). Equine chorionic gonadotropin: an enigmatic but essential tool. Anim. Reprod., 9(3): 223-230. https://www.animal-reproduction.org/ article/5b5a6057f7783717068b46e2

- NRC (1985). Nutrient Requirements of Sheep, 6th ed. National Academies Press. Washington, DC. pp. 99.

- Núñez-Olivera R, Cuadro F, Bosolasco D, de Brun V, de la Mata J, Brochado C, Meikle A, Bó GA, Menchaca A (2020). Effect of equine chorionic gonadotropin (eCG) administration and proestrus length on ovarian response, uterine functionality and pregnancy rate in beef heifers inseminated at a fixed-time. Theriogenology, 151: 16-27. https://doi.org/10.1016/j.theriogenology.2020.03.031

- Núñez-Olivera R, de Castro T, Bó GA, Piaggio J, Menchaca A (2018). Equine chorionic gonadotropin administration after insemination affects luteal function and pregnancy establishment in postpartum anestrous beef cows. Domest. Anim. Endocrinol., 62: 24-31. https://doi.org/10.1016/j. domaniend.2017.08.003

- O'Connell AR, Demmers KJ, Smaill B, Reader KL, Juengel JL (2016). Early embryo loss, morphology, and effect of previous immunization against androstenedione in 
the ewe. Theriogenology, 86(5): 1285-1293. https://doi. org/10.1016/j.theriogenology.2016.04.069

- O'Hara L, Forde N, Duffy P, Randi F, Kelly AK, Valenza A, Rodriguez P, Lonergan P (2016). Effect of combined exogenous progesterone with luteotrophic support via equine chorionic gonadotrophin (eCG) on corpus luteum development, circulating progesterone concentrations and embryo development in cattle. Reprod. Fertil. Dev., 28(3): 269-277. https://doi.org/10.1071/RD14019

- Russel AJF, Doney JM, Gunn RG (1969). Subjective assessment of body fat in live sheep. J Agric. Sci., 72(3): 451-454. https://doi.org/10.1017/S0021859600024874

- Samartzi F, Theodosiadou EK, Rekkas CA, Saratsi A, Lymberopoulos AG, Vainas E, Tsiligianni T (2020). Effect of equine chorionic gonadotropin on glycosidase activity in the reproductive tract of ewes, in relation to ovarian response and embryo yield. Small Rumin. Res., 191: 106186. https:// doi.org/10.1016/j.smallrumres.2020.106186

- SAS (2011). Base SAS ${ }^{\circledR} 9.3$ Procedures Guide: Statistical Procedures. SAS Institute Inc, Cary, North Carolina, USA. pp. 528.

- Van Lier E, Hart KW, Viñoles C, Paganoni B, Blache D (2017). Calm Merino ewes have a higher ovulation rate and more multiple pregnancies than nervous ewes. Anim. an Int. J. Anim. Biosci., 11(7): 1196-1202. https://doi.org/10.1017/
S1751731117000106

- Vergani GB, da Fonseca JF, Trevizan JT, Pereira VS do A, Garcia AR, Esteves SN, Brandão FZ, Souza-Fabjan JMG, Oliveira MEF (2020). Luteotropic effects of human chorionic gonadotropin administered 7.5 days after synchronous estrous induction in Morada Nova ewes. Anim. Reprod. Sci., 223: 106644. https://doi.org/10.1016/j. anireprosci.2020.106644

-Wecker F, Thedy DX, Gonsioroski AV, Borges JBS (2012). Efeito da aplicação de eCG ou hCG 7 dias após a IATF no desenvolvimento das estruturas ovarianas e nas taxas de prenhez de vacas de corte. Acta Sci. Vet., 40(4): 1072. http:// www.ufrgs.br/actavet/40-4/040-4.htm

-Weems YS, Pang J, Raney A, Uchima T, Lennon E, Johnson D, Nett TM, Randel RD, Weems CW (2014). Prostaglandin E1 or E2 inhibits an oxytocin-induced premature luteolysis in ewes when oxytocin is given early in the estrous cycle. Theriogenology, 82(3): 440-446. https://doi.org/10.1016/j. theriogenology.2014.04.024

-Wiltbank MC, Souza AH, Giordano JO, Nascimento AB, Vasconcelos JM, Surjus RS, Carvalho PD, Bender RW, Sartori R (2012).Positive and negative effects of progesterone during timed AI protocols in lactating dairy cattle. Anim. Reprod., 9(3): 231-241. https://animal-reproduction.org/ journal/animreprod/article/5b5a6057f7783717068b46e3 